\section{Post script}

The Freud/Jung Letters. Edited by William McGuire. Pp. xlii+650. (Hoganth Press, and Routledge and Kegan Paul: London, 1974.) £7.95.

THE publication of this volume marks an important contribution to the history of the psychoanalytical movement, comparable to the issuing, in 1954, of Freud's letters to Wilhelm Fliess. Following his communications with Fliess, this exchange of material with his later protagonist, Jung, formed another chapter in the development of Freud's ideas. It is, perhaps, as the chronicle of a fruitful but doomed relationship that the volume has its greatest appeal, and as such, it forms a useful pendant to the official versions which have been given by Ernest Jones and by Jung himself.

When reading the letters, one is struck by the extent to which differences were managed for such a long time. For those familiar with the account of the break as given in Memories, Dreams, and Reflections, the tolerance demonstrated by Freud in the last years is unexpected. Yet the need felt by both men explains the concessions, the reconciliations, even the tensions that led to the final parting. A letter sent by Freud in 1907 sums up the situation beautifully:

". . . now of all times I wish I were with you, taking pleasure in no longer being alone and, if you are in need of encouragement, telling you about my years of honourable but painful solitude... about the indifference and incomprehension of my closest friends, about the terrifying moments when I myself thought I had gone astray : . about my slowly growing conviction, which fastened itself to the interpretation of dreams as to a rock in a stormy sea, and about the serene certainty which finally took possession of me and bade me wait until a voice from the unknown multitude should answer mine. That voice was yours" (p. 82).

Amid the intellectual torpor of the Burghölzi Hospital, Jung responded in kind. The meeting of two such gifted minds inevitably acquired complications, for as Jung looked to Freud in terms of a father figure, so too the older man regarded his younger colleague as a son and heir. Freud wanted Jung to explore schizophrenia in the way that he himself had studied obsessional neurosis (p. 168). But even though Jung had begun to do that before the correspondence began, his reservations about an exclusively sexual origin for mental illnesses were evident from the first (pp. 4-5, 7, 79, and 138-139). Later, as Jung developed his own theories about the mind, disagreements became more marked. After Jung's lectures in America in 1912, an open break was inevitable and it came within a year.

Publications and personalities fill

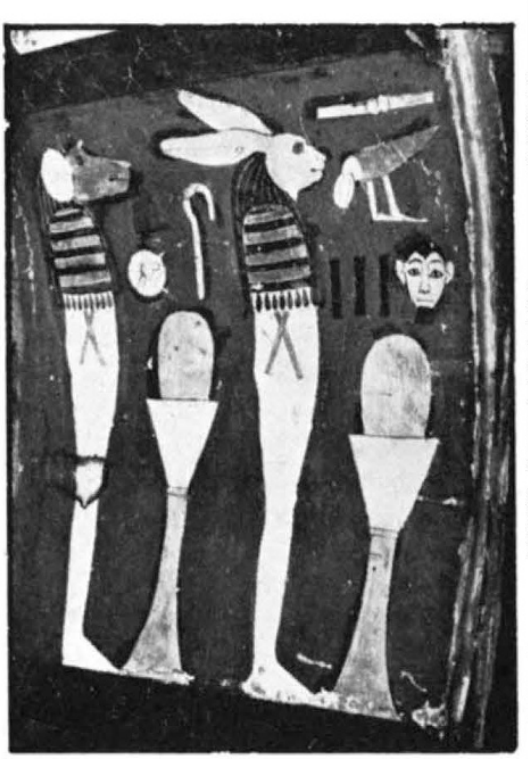

Hare-headed divinity of ancient Egypt on the coffin of Bakenmut, 21st dynasty. From The Leaping Hare. By G. E. Evans and D. Thomson Pp. $262+24$ photographs. (Faber : London, October 1974.) Paper, £1.50.

many of the letters, but the editor William McGuire aids the reader with footnotes which are concise as well as informative. It is a well produced book with lucid translations by Ralph Manheim and R. F. C. Hull, useful appendices, and an index. Finally, thanks should be given to the estates of both men for allowing the publication earlier than had been expected.

\section{B. A. Boucher}

\section{Fifty year's minutiae}

Half a Century of Medical Research. Vol. 1: Origins and Policy of the Medical Research Council (UK). A. Landsborough Thomson. Pp. xiv +308 . (HMSO: London, June 1974.) £4.60.

Worthy, rather than exciting, is the appropriate adjective for this book. It is the first of two volumes which will deal with fifty years of medical research in England. This first volume covers the history of the Medical Research Council and articulates the earlier principles of policy insofar as the future administration of the council and the future developments in scientific programmes are concerned. What comes out of this book-and, one can confidently expect, from the volume to follow-is almost every kind of fact and statistic that anyone interested in such matters could possibly hope for. Do you wish to know the details of the relevant Ministry of Health Act of 1919? Then this book will tell you just how this act was passed and how a very necessary legislative pro- vision was inserted to cover the question of "The organization of enquiry and research on health activities". Do you wish to know the minutiae of the administrative organisation of the Medical Research Council: which subcommittee was formed to do this or that; that the title Second Secretary, first used in 1949-57 and revived in 1965 , is now established for an officer able to act as the Secretary's secondin-command and deputy; that in 1914 rooms for temporary offices were taken at St. Stephen's House, Westminster, at a rent of $£ 25.00$ per annum, and that the council moved to Park Crescent in September 1961, into a building with a frontage of 255 feet with a depth of just over 42 feet? The book abounds in items like these.

As a living history I have to confess I find it lamentable, though as a compendium I find it invaluable. Nothing of the vibrating personalities emerges at all, nothing of people's real feelings, nor any real analysis of the infinite complexity of issues. So much is written up as a scientific Jennifer's Diary. We are told, for example, that on the occasion of the council's Jubilee Dinner, celebrated in November 1963, the Duke of Edinburgh was prevented from attending but that Lord Shawcross presided. In the absence of the Prince, The Right Honorable Quintin Hogg proposed the toast and a reply was made by Sir Henry Dale, but nothing of what was actually said on this occasion is recorded. Perhaps no-one really said anything-perhaps no-one knows; but I can hardly believe that. To add that: "The presence of Lady Fletcher and Lady Mellanby at the high table was particularly appropriate", may add something to our edification but nothing to our education.

This book is terribly safe; it says nothing controversial. There is very little that one can object to except that it is dull. Only a few notes of human vitality and spark emerge from the thumping melodic line. So, like drops of water in a desert, we read that the secretary of the council on February 2, 1939 wrote: "The discussion then wandered from the point and as we were both tired of cursing each other, we satisfied our minds by cursing everybody else". It is good to know that someone has a sense of humour. This is a book for the library but, unless you suffer from insomnia, it is not for the bedside.

I think it is a great pity that the sponsors have not been better served. The Medical Research Council, in achievements and policy, is an institution that we can contemplate with warmth and pride, and its history deserves a more vigorous and dynamic treatment.
June Goodfield 